\title{
Livelihood Strategies and Outcomes of Fisher Folks in Selected Rural Coastal Communities of Ghana
}

\author{
Isaac Eshun $^{1} \quad$ Harrison Kwame Golo $^{2} \quad$ Shirley Dankwa $^{3}$ \\ 1.Department of Social Studies Education. Faculty of Social Sciences Education. University of Education - \\ Winneba, Ghana \\ 2.Centre for Conflict, Human Rights and Peace Studies (CHRAPS). University of Education - Winneba, Ghana \\ 3.Centre for African Studies. Faculty of Social Sciences Education. University of Education - Winneba, Ghana
}

\begin{abstract}
People choose livelihood strategies that provide them with livelihood outcomes. For those living in poverty, livelihood strategies are usually varied and often complex. This study explores the livelihood strategies and outcomes of fisher folks in rural coastal communities. This paper focuses on two sub-themes: livelihood strategies and livelihood outcomes of fisher folks in four selected rural coastal communities in the Volta and Central Regions of Ghana. This study adopted a mixed method research approach with a sequential mixed method research design. The population included fisher folks - fishermen, fish mongers, fish processors, boat owners, net owners, outboard motor owners, middle men and women in the fishing industry in the selected communities. Eighty purposively sampled respondents were tasked to respond to interpreted and aided in answering questionnaires since most of them could not read and write. Twenty fisher folks were interviewed from each of the four communities. In addition, one focus group discussion (fgd) was held in each of the four communities. In testing for consistency of findings, interpretative technique was employed in analysing the qualitative data, whilst simple percentage was employed for the quantitative data collected. The research established three predominant livelihood strategies pursued in the study settings. These are livelihood diversification, intensification and migration. The livelihood outcomes they aimed to achieve were to: improve health and wellbeing; increase food security; have access to resources; increase income; and decrease vulnerability. The study categorised fisher folks who strive to achieve their livelihood outcomes into three, namely, 'positive', 'mid', and 'negative'. The study recommended the need for investment in livelihood activities within rural fishing communities as a way of broadening fisher folks' entitlements and capabilities.
\end{abstract}

Keywords: Capabilities, Coastal Communities, Empowerment, Fishing, Ghana, Livelihood, Livelihood Strategies, Livelihood Outcomes.

DOI: $10.7176 / \mathrm{JCSD} / 48-05$

Publication date:May $31^{\text {st }} 2019$

\section{INTRODUCTION}

The fishery sector provides subsistence livelihood for many people worldwide when and where there are few alternatives (Allison \& Ellis, 2001). This is premised on the fact that it is an open access, therefore becomes a fall-back option especially for the rural poor when they lose their land or fail to access other activities for their livelihood (Townsley, 1998). The fishery as a result contribute significantly to livelihoods around the world (FAO/IFAD/WB, 2009) by providing food security, income and employment through various activities in its three sub-sectors: harvesting, processing and marketing [International Collective in Support of Fishworkers (ICSF), 2006]. "In 2008, it was estimated that two hundred million people around the globe were directly or indirectly dependent on fisheries and aquaculture, out of which the majority are involved in small-scale fisheries" (FAO/IFAD/WB, 2009, p. 21).

In Africa, the fishery sector plays an important role by providing sources of employment to a large number of households. It was reported that, about 6 to 9 million people in sub-Saharan Africa depend on the fishery sector as a source of income (Béné \& Heck, 2005; Koranteng, 2010). Apart from its contribution to employment, the fishery also plays an important role in the provision of nutrition and food in many households in Africa. A study by Béné and Heck (2005) found that, fish provides about 22 per cent of dietary protein intake in subSaharan Africa.

In particular, fishery is very vital in terms of livelihoods in Ghana. It is estimated that, ten percent of the country's population is either directly or indirectly dependent on fishing (Mensah, Koranteng, Bortey \& Yeboa 2006; Akyeampong, 2007). Fishery sector in Ghana is not only open access, but also largely rural in character. It generates both direct and indirect employment for a large number of rural people who work as crew members, fish processors, traders, fish distributors and porters along the entire coastal zone of about 550 kilometres, stretching from Aflao in the East to Half Assini in the Western part of Ghana (Bank of Ghana, 2008). This is summarised in Table 1 below: 
Table 1: Ethnic groups within the coastal zone of Ghana

\begin{tabular}{llcc}
\hline Region & Coastal Ethnic Group & Coastline $(\mathrm{km})$ & No. of fishermen \\
\hline Western & Nzema & 105 & 6,750 \\
& Ahanta & 80 & 10,990 \\
Central & Fante & 150 & 28,300 \\
& Awutu-Effutu & 25 & 6,450 \\
\multirow{2}{*}{ Greater Accra } & Ga & 45 & 16,150 \\
& Dangbe & 70 & 13,370 \\
Volta & Ewe & 75 & 14,355 \\
\hline
\end{tabular}

Source: Coastal Zone Profile cited in Mensah et al. (2006, p. 37).

As indicated in Table 1, the fishery sector plays a major role in poverty alleviation (Mensah et al. 2006) because it serves as a source of employment to about 1.5 million people living along the coastal fishing communities in the country (FAO, 2004). The livelihood of these rural coastal communities in Ghana is, therefore, heavily dependent on fishing in that, most of the trade and processing is carried out by people belonging to the industry (Mensah et al., 2006). According to Mensah and his colleagues, the older women carry out the fish processing, assisted by younger women or hired labour. Akyeampong (2007) thus argues that, fishing is an occupation that constitutes an integral part of the life and identity of coastal fishing communities in Ghana. Within these communities, children at a very tender age are trained to acquire all the necessary knowledge, attitudes, skills as well as values that are associated with fishing and fish processing (Mensah et al., 2006; Afenyedu, 2010).

Despite these contributions, the fishery sector always suffers from weak regulatory policies, which are inadequate for the implementation of the reform processes. Already, Ghana's first Poverty Reduction Strategy Paper (GPRSP) identifies the traditional fishing communities in the country as poor and vulnerable (DfID, 2004). Elsewhere, Béné and his colleagues contended that, "the failure of many fishery programmes to enable fisher folks to improve livelihood are due to lack of understanding of the complex livelihood strategies and the relationship between economies, social aspects and institutions that characterise small-scale fishing communities" (Béné, Macfadyen \& Allison 2007, p. 13). On another wavelength, Golo and Eshun (2018, p. 14) assert that "Climate change related events are directly or indirectly affecting residents' rights of subsistence in the study communities. Residents' enjoyment of rights to adequate water, food and housing are seriously undermined as a result of the harsh outcome of the phenomenon exerting on their livelihood." In the view of Golo, Attom, Brew and Eshun (2018, p. 51) "Sustainable livelihood strategies like resourcing identified vulnerable families to carry out viable ventures will help to reduce poverty in the catchment zone." This implies that sustaining desired livelihood and managing vulnerability should be given serious attention. This paper, therefore examines the dynamics of livelihood strategies and outcomes of the fisher folks in selected rural coastal communities in the Central and Volta Regions of Ghana. The understanding of these dynamics is supposed to facilitate appropriate poverty reduction intervention mechanisms in rural costal fishing communities in the country.

\section{LITERATURE AND CONCEPTUAL VIEWPOINTS ON LIVELIHOOD AND LIVELIHOOD STRATEGIES}

\subsection{Livelihood}

A livelihood "comprise the assets (natural, physical, human, financial and social capital), the activities and the access to these assets (mediated by institutions and social relations) that together determine the living gained by individuals or household" (Ellis, 2000, p. 10). "The livelihood concept seeks to bring together critical factors and activities which affect the vulnerability or strength of household strategies" (Allison \& Ellis, 2001, p. 378). The approach is perceived as an attempt to capture not just what people do in order to make a living, but also the resources that provide them with the capability to build a satisfactory living. Livelihood is deemed sustainable when it can cope with, and recover from stresses and shocks and maintain or enhance its capabilities both now and in the future, while not undermining the natural resource base (DfID, 1999).

The livelihood approach assumes that, people pursue a range of multiple livelihoods that are drawn on a range of assets to pursue the various activities (Farrington, Carney, Ashley \& Turton, 1999). The accessibility to these assets gives support to livelihood strategies that, in turn, produce livelihood outcomes. "The livelihood approach is a realistic recognition of the multiple activities in which households engage to ensure their survival and to improve their well-being" (Rakodi, 2002, p. 9). The approach is vital for a study that addresses the relationship between the means and activities through which people make a living and the resources they have at their disposal. It is primarily used as a sensitising concept which points to a people-centred and non-sectorial approach to poverty, and is grounded in the multi-faceted reality of life (Kaag, van Berkel, Brons, De Bruijin \& van Dijk, 2003). The livelihood approach was developed as a response to poverty research and focuses on "what the poor have rather than what they do not have" (Moser, 1998, p. 1). It is, therefore, sounds reasonable by 
researching into the livelihood strategies and outcomes of fisher folks in selected rural coastal communities of Ghana.

This has become necessary because the livelihood approach provides not only a very effective framework for understanding the complexity and diversity that characterise the nature of poverty and the livelihood strategies of the poor, but also, directs how interventions can best be tailored to enhance livelihood (Kaag et al., 2003). As a consequence, the approach gained wide acceptance as a valuable tool for understanding the factors that influence lives among the rural poor (De Haan, 2006).

As a response to the growing awareness of poverty in rural coastal communities and the lack of attention they receive, there have been researches conducted using the livelihood approach. These studies analyse the extent to which the poor benefit from economic situation, and identify how present development strategies impact on these poor communities. Allison and Ellis (2001), for example, employed the approach to small-scale fishery research. They commented that, the description of the development of the fishery sector tends to limit its focus to what small-scale fishers lack, without paying attention to what they have (Allison \& Ellis, 2001). Consequently, many modernisation programmes undermine the adaptive capability of small-scale fishery due to lack of understanding of small-scale fishers' livelihood (Platteau, 1989). These militating factors, therefore, call for the need of prescribing meaningful livelihood strategies.

\subsection{Livelihood Strategies}

Livelihood strategies and livelihood portfolio, according to Scoones (1998, pp. 6-10), are synonymous, and are used to describe the ways in which people draw on and combine various assets at their disposal to pursue their livelihood. Scholars have shown that, households develop strategies that enable them to generate income, using available resources as fully as possible (De Haan \& Zoomers, 2003) to constructs and increase diverse portfolio of activities and assets that will enable them survive and improve their standard of living (Ellis, 2000). This shows the reason why current economic crises have compelled many households to resort to diversification of income sources and strategies to improve their standard of living.

Maxwell (1999) distinguishes between diversification of income-generating strategies and a variety of coping strategies, while Scoones (1998) identifies three types of strategies or portfolios in his review of conceptual issues of rural poverty. He explains that poor rural households adopt three major livelihood strategies, which he referred to as (i). agricultural intensification and extensification; (ii). livelihood diversification, including paid labour, rural enterprises; and (iii). migration. Ellis (2000) in his framework, categorised livelihood strategies as: natural resource based activities or non-natural resource based activities, such as remittances and other transfers.

While recognising attempts by a number of scholars to redefine this concept, this study embraces Rakodi's assertion that, the concept 'livelihood strategy' has the advantage of restoring agency to poor people, instead of regarding them as mere passive victims (Rakodi, 2001). In the light of the above, this study uses this concept to describe the actions and decisions of individuals and households within rural coastal fishing communities of the Volta and Central Regions as people with capability and agency, whose decisions and actions concerning their lives are shaped by constraints.

Ellis (2000) emphasises that, diversification is pervasive and enduring in the sense that the phenomenon occurs everywhere and seems to transient societies. Studies have indeed shown that, there is enormous diversity of livelihood strategies at every level in a geographical area and across sectors within a household (DfID, 1999). The vast majority of rural households in sub-Saharan Africa, according to Ellis (2000), are increasingly reliant on the construction of a diverse portfolio of activities and income sources in order to survive and to improve their standard of living. He identified seasonality, risk, labour markets, credit substitution, and asset strategies, as well as investment to enhance future livelihood prospects, such as developing networks and education, as factors which induce voluntary motives for the adoption of diverse livelihoods.

However, livelihood activities are sometimes introduced as a coping strategy in times of crises. A growing body of research in rural Africa document a wide range of livelihood strategies as a response to crises. In their studies of livelihood strategies in Africa during the early 1990s, Dietz, Druijven and Foeken (1992), for example, found that households could be engaged in different household livelihood activities, as micro decision units and partly in inter-household net-works of mutual assistance. The typology of livelihood strategies identified by them include: accumulation strategies (improving the means of production); betterment strategies (improving consumption situation); sustenance or adoptive strategies (social manoeuvring to preserve a consumption and/or wealth level); mechanisms to cope with seasonal stress; and survival strategies to cope with exceptional crises. It is argued in this study that, the livelihood strategies evolved by fisher folks in the rural coastal communities should aim at achieving livelihood outcomes which will reduce vulnerability and in turn, increase their wellbeing. Consequently, if the outcomes of the livelihood strategies adopted are positive, they should be able to improve incomes, increase well-being and reduce vulnerability (in terms of shocks, seasonality and unfavourable government policies) (Rakodi, 2001) of fisher folks in the study setting. 


\subsection{Livelihood Strategies in Fishing Communities}

Numerous studies have testified to the fact that, the livelihood strategies in fishing communities are diverse and complex, reflecting the variation in opportunities available to them (IMM, 2003; Kleih, Greenhalgh, \& Oudwater, 2003; Lensenlink, 2002). This body of scholarly documents revealed that, poor fishing communities engage in various livelihood strategies as a way of managing risk. Among these are strategies to: (1). increase family size so as to ensure that children are engaged in productive work at a very tender age instead of schooling; and (2). increase resources by relying on more intensive technologies resulting in further degradation, greater competition and indebtedness (IMM, 2003; Kleih et al., 2003).

A study by Lensenlink (2002) in Guinea, Mauritania, Ghana and Senegal also identified two groups of livelihood strategies, which he classified as: general and fishing related strategies adopted by fishing communities to counter the influence of vulnerability and to increase well-being. The fishing related strategies, according to him, include (1). the use of flexible and diverse fishing practices to spread risk over various species and markets, (2). seasonal or permanent migration to richer fishing areas to ensure year-round income, and (3). the marketing of different type of products in addition to fish. The general strategies, on the other hand, take the form of multiple income earning activities, such as investment in social relations and groups for social security, saving and investing in assets such as land, housing and business to secure security and income in the future.

Evidence from fishing communities concerning diverse livelihood strategies is often associated with the adaptation to changing circumstances (IMM, 2003). Risk reduction, responding to seasonal change, declining options, dealing with shocks and unfavourable government policies are some of the factors identified as the major reasons why poor households and individuals within fishing communities diversify their livelihood strategies (IMM, 2003). Thus, the concept of household strategies is frequently invoked in Third World research to describe what the poor do, as well as explaining why they do it (Wolf, 1992).

\section{METHODOLOGY}

The study employed the mixed method research approach which is a combination of both qualitative and quantitative in collecting data. In the words of Tashakkori and Teddlie (1998, pp. 17-18), cited in Baidoo, Dankwa and Eshun (2018, pp. 10-11) the mixed methods (quantitative and qualitative methods) are "those that combine the quantitative and qualitative approaches into the research methodology of a single study or multiphase study." Sequential mixed method research design was employed. This was guided by the major themes in the research.

This study focuses on two themes: livelihood strategies and livelihood outcomes of fisher folks in four selected rural coastal communities in the Volta and Central Regions of Ghana. The four rural coastal fishing communities were namely, Agavedzi and Tetekorfe in the Volta Region and Brenu Akyinim and Kafodzidzi in the Central Region. The population included eighty fisher folks which were made up of fifty-five males and twenty-five females from the selected communities. Purposive and convenience sampling techniques were employed in selecting the fisher folks. Eighty purposively sampled respondents were tasked to respond to interpreted and aided in answering questionnaires because most of them could not read and write. Twenty fisher folks were interviewed from each of the four communities. In addition, one focus group discussion was purposively held in each of the four communities.

Triangulation was employed to test the consistency of findings obtained through different instruments. The triangulation of data from multiple cases helped the researchers to generate conclusions based on multiple instances and unique occurrences. Ethically, the real names of respondents were replaced with pseudonyms to protect their identities. Interpretative analytical technique was employed in analysing the qualitative data, whilst simple percentage was employed in analysing the quantitative data collected. The data from the in-depth interviews and focus group discussions were transcribed and classified according to common themes using analytic coding, noting and followed with the description of the phenomenon from the perspective of the respondents.

\section{FINDINGS}

\subsection{Livelihood Strategies}

Three categories of livelihood strategies were identified and employed by both the poor and the wealthy fisher folks in responding to their socio-economic situation in the four study communities. These are intensification, diversification and migration (see Figure 1. below). 


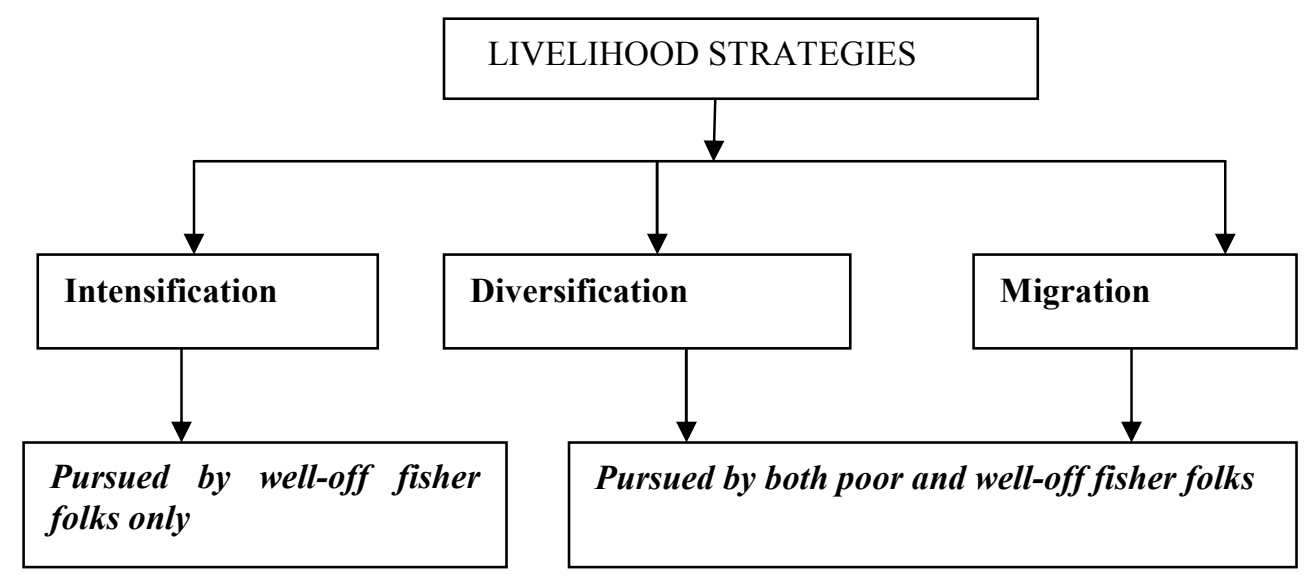

Figure 1: The categories of livelihood strategies pursued by fisher folks in the four study communities.

Source: Fieldwork, 2018.

In general, the livelihood strategies undertaken by fisher folks in the study settings were limited to intensification, diversification and migration as shown in Figure 1. These are discussed below:

\subsubsection{Intensification}

Intensification as a means adopted by fisher folks in pursuing their livelihood involves increased inputs of labour. It is characterised by a substantial increase in fishing inputs and the labour of fishing crew to increase catch and income. Most of the fisher folks who adopted the intensification portfolio live in polygamous unions with large family sizes. They have well established income-generating activities and fairly adequate access to financial and physical capital. It is not surprising then that, they are able to provide the necessary basic needs of their households. They exert power and authority in the fishing business in the sense that, the fishing crew rely on them for the security of their livelihood.

The respondents who pursue intensification also invest in various types of fishing equipment, including fishing boats, nets and outboard motors to facilitate their fishing activities. According to them, they hire fishing crews for about ten months or more on contract basis and remunerate them at the end. They explained that, while the crews were at times rewarded with fish or cloths, they (the crew) were also obliged to take loans from them. This is done on condition that, the crew continues working with them for another period of time.

Respondents, however, explained that in recent years they had not been able to increase income through intensified strategies due to rising prices of fishing inputs, pre-mix fuel and low catches. The result indicates that, only few of fisher folks intensify their activities in pursuing their livelihood. Out of eighty fisher folks involved in the study, $5(6.2 \%)$ were found within the intensification bracket. This implies that, intensification is less dominant livelihood strategy in the study locations. This is shown in Figure 1 as a strategy pursued by only the well-off fisher folks.

\subsubsection{Diversification}

This study has established that, both the poor and well-off fisher folks with various occupational backgrounds combine a range of activities to generate extra income. The portfolio of primary activities identified to be taken by the fisher folks include: petty trading; cooked foods and raw food-stuffs; selling of their labour and that of their children; hiring of labour; and livestock and poultry keeping.

Diversification strategy was pursued by both the poor and well-off fisher folks. Out of the 64 respondents within the diversification bracket, $49(76.6 \%)$ of those who earn their primary income from petty trading and fish processing/trading generate additional income from the sale of other items like clothing, cooking oil, alcoholic beverages and food stuffs. This category of respondents explained that they also derived both financial and nonfinancial capital from the membership of their association. According to them, this makes it easier to access other types of capital to support their household needs and also to invest in other income-generating activities. Many of the fisher folks who own nets and boats, also stated that, they supported their spouses financially to take up petty trading in order to generate additional income for their households. Poultry farming and keeping of livestock, such as pigs and goats are also common among a few number of net and boat owners. It is not only fish processors/traders and boat and net owners who are in this group. Others also traded in items like exercise books, pencil, eraser and snacks, clothing and children's wears as well as hair products to generate extra income. Many of the fisher folks in this category are able to engage other people, especially children and women through paid labour in their extra income activities. This enables them to combine the activities described above, as recounted by a respondent during one of the fgd sessions: 
"Combining many works at a time can be very hectic and taxing, so we normally hire paid labour, especially, young girls and boys or their parents from the community to assist us" (fgd, 29 $9^{\text {th }}$ June, 2018). A net/boat owner, who also happened to own a fishing company, reported during the in-depth interview that he hired the labour of boys on many occasions to assist in mending his fishing nets. (Interview with Atisa, $21^{\text {st }}$ June, 2018).

In general, the majority of fisher folks who fall under this group of livelihood diversifiers have large families. However, they have enough assets that enable them to provide for their needs and general well-being. Many of these fisher folks, especially the fish processors/traders earn high and medium income from their activities and also belong to one or two associations. Almost all the respondents in this group were registered National Health Insurance Scheme members. This enables them and their household members to seek medical care in government hospitals. The majority of them are able to either send their children to school or sponsor them in learning trades. On diversifying their livelihood, a respondent had this to say:

There is the need for extra livelihood activities to enable me generate additional and regular income for the promotion and protection of my well-being and that of my household members. This will help me to have the needed resources to provide them with good nutrition and proper health care (Interview with Fiifi at Kafodzidzi, $30^{\text {th }}$ May, 2018).

In contrast, diverse portfolio of activities pursued by 'poor' fisher folks in the study area is limited to selling their labour and that of their spouse and children in diverse ways. This category of respondents is also characterised by large family sizes, polygamous homes, but they have very limited capital and no access to the activities of diversification described above, hence most of them are overwhelmingly heavily indebted. As expected, most of the fisher folks in this group indicated that they struggled to secure regular daily meals for their survival and that of their household members. According to many of them, the basic economic security which would have ensured access to health care, education and food for their children is lacking. Hence, their households often resort to traditional self-medication for their health care. They explained that, inadequate food and lack of proper medication have, in turn, hampered their ability to work effectively to earn extra income. The case of Koku illustrates the life of poor fisher folks who follow diversification.

$\mathrm{K}$ oku is a 50 year old fishing crew with eleven children. He is in a polygamous marriage with two wives and has a low income. Koku explains that in order to ensure a year round income for food and general well-being of his household, he engages in extra income-generating activities by working hard in both sea and lagoon fishing and also assists traders at the Ghana-Togo boarder to enter Ghana or Togo with their wares. Koku also used to earn extra income from sand winning at the beach but the District Assembly has put a stop to the practice in order to prevent excessive sea erosion in the area.

To supplement his income, his wives and children also sell their labour to fish processors and net owners. His children, especially the boys go to the beach almost every day to assist the fishermen in folding or mending their nets for a fee or fish for the household, while his two wives combine working for fish processors with other works like carrying goods for traders at Denu market. During the dry season, Koku and his wives also engage in salt harvesting from the dry lagoon. Despite the fact that Koku wants all his children to attend school, the harsh conditions he finds himself has left him with no other choice than to withdraw them.

\subsubsection{Migration}

The categories of fisher folks who pursue this strategy involve both the poor and wealthier ones, with small or large household sizes. When they were asked why they migrate, they provided reasons, among others: raising money for fishing equipment, settlement of debts as well as provision of food and clothes for themselves and the members of their households. Although migration has been an important livelihood strategy, the crews reported that, their decision to migrate depended on their access to a fishing company or the willingness of the company owner to employ them. According to them, the net and boat owners normally employ them because of (the crew's) good health and ability to work for long hours. The result indicates that out the 64 respondents within the diversification bracket, $15(23.4 \%)$ in one way or the other, follow migration. The situation of poor fisher folks who adopt migration as a livelihood strategy is seen in the following case:

Kobla is a 49-year-old fishing crew with two wives and eight children ranging from 3 to 16 years of age. He lives in three thatch houses with a common compound. Kobla has never been to school, and has no other skills besides fishing. He has been working for the past 28 years as a fishing crew and migrated to different countries, namely Gambia, Gabon, Togo, Benin and Liberia with different fishing companies. Kobla explained that, migration for fishing helps him to save a small amount of money to settle his debts and such fishing expeditions help to save some money. This helps to solve some of his financial problems, including providing for his family, especially when the season is good. He noted, however, that he sometimes returns home with nothing or only a small amount of money during bad seasons. In such situations, he borrows money from his employer who deducts it at source on subsequent trips.

When asked why he could not save enough to acquire his own fishing equipment or to invest in other income 
generating activities, he remarked that:

Fishing crews normally do not make enough money because of the way they are rewarded. According to him, at the end of their expedition, the catch is normally divided into five. Two fifths $(2 / 5)$ for the net owner, one fifth $(1 / 5)$ for the leaders and the remaining two fifths are divided among the crew. The net owner, in turn, deducts the loans he lends to them before giving whatever amount is left. Fishermen are likely to contract another loan and then keep working for the master until they are able to settle their loans finally. As a result, the crew works for the net owners and just for their own survival but not to earn enough money.

The overall distribution of the results with respect to the identified categories of livelihood strategies in the study communities, most of the sampled fisher folks $(80 \%)$ resort to diversification. Fisher folks that pursue migration constitute the second largest group (13.8\%). This is followed by those who pursue intensification $(6.2 \%)$.

\subsection{Livelihood Outcomes}

Livelihood outcomes are the achievements of livelihood strategies. The three types of outcomes the fisher folks aimed to achieve are categorised as 'good health and well-being', 'food security and access to resources' and 'increase in income and reduce vulnerability'. These are assessed as follows:

4.2.1 Improvement in health and well-being: This refers to the fisher folks' ability to secure physical, mental and social well-being as well as a sense of control and access to services. It is worthy to note that, good health and well-being of people is generally determined by the physical environment in which they live as well as their access to both financial and physical capital. Data from this study suggest that, good physical health is among the central objectives that fisher folks aimed to achieve for themselves and their household members. This was emphasised by one of the respondents as follows:

The reason why I keep myself busy every day is not because of material things only, but also to ensure the health of my children and my wives and, of course, myself. Good health helps us to carry out our daily activities to generate enough income. That is why nobody feels secured and happy when a member of the household is ill (Interview with Papa Kwamena, $21^{\text {st }}$ June, 2018).

Most of them reported, however, that their efforts to maintain good health have been constrained by many factors, such as financial difficulties and high prices of food and medicines. Other problems are unhygienic sources of drinking water and poor sanitation. In addition to all that, they have less access to health care facilities. On the basis of the above factors, most of the respondents indicated that, they are not able to maintain or improve on the good health and well-being of their households. Out of the 80 respondents, only $22(27.5 \%)$ said they have improvement in their health and well-being.

4.2.2. Increased food security and access to resources: All the fisher folks noted that, one of their priorities was to access more resources. Also, to increase food security in order to meet their households' nutritional and material requirements for a secured well-being. However, a large number of them indicated that, they experienced constraints, such as lack of productive and financial capital to enhance their productivity. That is, although all the respondents engaged in various income-generating activities, some could not earn enough income to enable them secure adequate food and more resources. Consequently, only $31(38.8 \%)$ of fisher folks indicated that, they were able to achieve their livelihood objectives by securing sustainable, sufficient and adequate resources as well as food security to meet the basic needs of their families.

4.2.3. Increase in income and decrease in vulnerability: Fisher folks engage in various income-generating activities to increase their income with the aim to reduce vulnerability. However, most of them stated that, they faced challenges like poor access to assets, seasonal changes and other distressful situation induced by volatile price fluctuations for food and other basic needs. The above situations, according to them, have hampered their ability to raise their income in the various activities they engage in. Hence, most of them stated that, they remained susceptible to numerous predicaments, such as shocks and stress in their daily lives. In the results, only $27(33.8 \%)$ fisher folks were able to have a secured income, and were thus, able to reduce their vulnerability.

\subsection{Livelihood outcomes: 'Positive', 'Mid' and 'Negative'}

In the previous section it has been documented that fisher folks within the communities under study belong to different categories in terms of achievements of their livelihood outcomes. This section classifies them in relation to their achievements, namely 'positive, 'mid' and negative' outcomes. These are elaborated below:

\subsection{1 'Positive' livelihood outcome}

Fisher folks who are able to achieve their identified livelihood incomes have either physical assets (boats, nets, outboard motors and fishing companies) or engage in established income-generating activity/activities with regular income. Many of the respondents within this category of fisher folks live in decent and spacious houses with electricity, toilet and private sources of water. Although the majority of respondents in this category have large household sizes, they are able to ensure their well-being through the provision of sufficient and nutritious food and quality health care. Moreover, many of them are able to intensify their livelihood strategies through 
cheap or paid labour and other services. Apart from that, most of them are characterised by social support networks which they use to facilitate their access to both financial and non-financial capital.

In general, this category of respondents and their household members live quite a dignified life, and are accorded much respect in their various communities. Some of them, especially the net and boat owners, are very influential in terms of major decisions pertaining to their respective communities and have a number of both old and young people working for them for a fee. From the results, out of the 80 fisher folks, $15(18.8 \%)$ were able to achieve their livelihood outcomes. It is important to note that, 31.2 per cent of them were women; most of them fish processors/traders. Also, striking is the fact that, all these women were either divorced or separated but had children aged between four and twelve years, ranging from four and seven in number.

\subsection{2. 'Mid' livelihood outcome}

Fisher folks who are striving to achieve their livelihood outcomes (Mid livelihood outcome) have smaller families than both the rich and the poor. Many of them are neither very poor in physical assets nor very low in terms of income. They are between the poorest and well-off fisher folks. This group has medium income from their activities. They are poor in terms of assets but they may succeed in achieving their identified outcomes. Most of them have access to financial capital, such as loans. These are often obtained from the boat and net owners as well as fish processors and traders.

The majority of the respondents in this group are between 20 and 30 years old with two or three children. They are able to work for long hours but rely mostly on owners of fishing boat for their main income-generation. Many of them practice diversification and migration portfolio as means of earning a living. They are able to provide adequate food as well as health care for their households. This category of respondents has no money to save but they are able to meet their basic needs and that of their family. A few of them have access to social capital. Many of them actively participate in social activities as well as decisions pertaining to various issues in their respective communities, although they are less influential than the community members belonging to the 'positive category'. Only 7.5 per cent of the sampled fisher folks belonged to this group.

\subsection{3. 'Negative' livelihood outcome}

Fisher folks who are unable to achieve adequate livelihood outcomes lack fishing equipment and other capital that can be used in fishing or other income-generating activities to ensure their well-being and that of their household members. As a result, they depend on boat and net owners as well as fish processors and traders in most of their income-generating activities. Most of these fisher folks depend heavily on fishing but also follow diversification and migration as means to earn extra income. Yet, the diversified activities that they follow are confined to selling their labour and that of their household members. Apart from the migration they pursue, they are also subjected to the control and approval of the boat and net owners who employ them. Thus, even though they work hard, the decline in the fishery resources and their limited option for livelihood diversification as well as limited or no access to productive assets prevent them from earning enough income.

Apart from that, they are also indebted and have more dependant members in the households. To the extreme, a significant number of them barely provide education for their children as well as food and cloth for themselves and their household members. Consequently, the whole family often has only one meal or sometimes pass a whole day without eating. As a result, their children take to working at very tender age in order to either fend for themselves or contribute to the households' income. They wear tattered cloths and live in overcrowded thatched houses with no access to social amenities like electricity, potable water and toilet. Many of their children are malnourished, often stunted, and unhealthy. They and their household members do not seek medical care at government or private hospitals but resort to self-medication. Given the above challenges, they are often unable to maintain their good health and general well-being.

Furthermore, many of them do not have access to social capital from which they can derive financial benefit, since they cannot meet the membership requirements. They find it impossible to access loans from banks or individuals. Most of them have a very low social status and can hardly participate in or influence decisions pertaining to socio-economic and political issues in their various communities. Also, in view of the fact that they are under-represented, many of them have become a prey to exploitation by the privileged in their communities. Majority, 59(73.8\%) of the sampled fisher folks fell in the 'negative' livelihood outcome category. The case of Fofovi illustrates the situation of the negative fisher folk household heads.

Fofovi, a 47-year-old fishing crew, is the main breadwinner in his household. He is married with six children and lives in the same house with his 85 year old mother and his late brother's son. Fishing has been his main regular source of income ever since he married. With time the household had to resort to odd jobs like working on market days as head porters at the Denu market. His eldest child, who could help him out, is not working because of health problems. Initially, Fofovi resorted to migration as a way of improving his finances and catering for his household. However, he is no longer doing this because his employer has laid him off. Fofovi was sacked because he had been indebted to his employer over the past 5 years or so. He has not been able to solve this problem because of the low catch nowadays. He bemoans that life has been difficult for him and his entire household, since he was 
laid off by his employer. According to Fofovi, he initially contemplated leaving the village to Benin or Gabon to look for a job as a fishing crew, but he had to rescind his decision due to his current state of health.

Concerning his household's health care and clothing, this is what Fofovi had to say:

Due to financial difficulties we cannot go to the hospital when we fall ill, I resort to treating my children, my wife and myself with herbal medications that my late father taught me. As for clothes [...] what you see us wearing now is all that we have. For me, what my family will eat is more important than what to wear $[\ldots]$ that is why we stopped attending social gatherings.

At the time of the interview, Fofovi told us that his former employer had been threatening to take him to court unless he was ready to settle his debt within three months. However, Fofovi recognises that he has not got enough strength and energy, and as such wants to place two of his sons under bonded labour with his former employer for them to work and defray the debt on his behalf.

\section{DISCUSSIONS}

Outcome of intensification as a livelihood strategy indicates that fisher folks who pursue it in combination with other portfolio of activities are mostly boat and net owners. The observation seems to be part of the general trend whereby fisher folks who have more access to both physical and financial capital are able to hire the labour of other people to intensify their various income-generating activities (livelihood strategies). This finding suggests that fisher folks' decision to pursue or not to pursue the intensification option is, to some extent, contingent on availability of physical and financial capital as well as labour (Scoones, 1998). Fewer number of fisher folks employing the intensification strategy implies that, the well-off fisher folks may have less or no alternative source of livelihood due to lack of skills in other trades.

Another livelihood strategy fisher folks adopt is diversification. Main features of diversification category of fisher folks are that, despite their efforts to follow extra portfolio of activities to boost their income, they still remain generally poor, powerless and exposed to various types of risks and stress in their daily lives. Literature on rural livelihoods in coastal communities indicates that diversification is a central feature of most households' livelihood strategies (Allison \& Ellis, 2001; Ellis, 2000). As evident in the current study, both the well-off and the poor pursue diversification as a livelihood strategy. However, factors such as access to capital determine the type of diversification activities fisher folks pursue. Poor fisher folks who engage in extra income activities do that to save money, settle their debts and provide food for themselves and members of their household. On the other hand, the well-off fisher folks undertake such activities with the aim to improve their livelihoods and also to invest in production. The finding supports studies, which suggest that diversification and building of diverse portfolio of livelihood options is the primary means through which many households reduce risk and cope with uncertainty (Ellis, 2000). De Haan and Zommers (2003) reason along similar line that diversification can be both a coping and an adaptive strategy or can be posed as the contrast between survival and choice. This implies that, the more livelihood activities fisher folks engage in, the more resilient they become in the sense that, they have the possibility to alternate between the various activities in times of need.

Migration as a livelihood strategy has long been a common and vital phenomenon among rural artisanal fishermen in Ghana (Mensah et al., 2006; Anarfi Kwankye, Ofosu-Mensah, Tiemoko (2003). Migration in fishing communities involves temporal or seasonal mobility within and outside the country in search of better fishing grounds to avert poverty or increase wealth. This particularly, holds true for fisher folks in both Central and Volta Regions. Information gathered in this study suggests that, fishermen in the regions engage mostly in cross border migration to countries such as Togo, Gabon, Nigeria, Benin, Cote D'Ivoire, Liberia, Sierra Leone, the Gambia, etc. for fishing expedition on permanent or temporal basis. Migration has also been identified as one of the important strategies pursued in the communities by both the wealthy and poor fisher folks with the aim to better their welfare or increase their financial and physical capital. It is worthy to note that, the pattern of the migration reflects a level of access to assets and dependency. As evident in this study, the migration option for the fishing crew, in particular, is heavily dependent on the boat and net owners who employ them for their fishing companies. The inference here is that it may not be possible for every crew in the study area to pursue migration on a regular basis. The finding that fisher folks in the communities under study migrate to neighbouring countries for better fishing opportunities corroborates other studies like Bortei-Doku (2002), Anarfi et al. (2003) and Mensah, Koranteng, Bortey and Yeboa (2006) who found that most Ghanaian fishermen can be found in Togo, Benin, Cote D'Ivoire, as well as Congo, Sierra Leone, Gambia and Guinea.

Livelihood outcomes seen as the achievements of livelihood strategies are under three types of outcomes the fisher folks aimed to achieve. These are categorised as 'good health and well-being', 'food security and access to resources' and 'increase in income and reduce vulnerability'. Improvement in health and well-being or good health is always regarded as wealth, implying a person who is in that state can labour and generate income that can, in turn, reduce vulnerability and food insecurity. In similar vein, good health of household members is also seen as a priority to the entire household. Inability of fisher folks to achieve the above outcomes suggests 
the existence of poverty and vulnerability within the study settings.

Hence, they do not only become heavily indebted, but also lack access to assets to enable them generates enough income to ensure good health and general well-being for themselves and their household. The finding confirms the livelihood theory that, the type and number of assets that individuals command do not only determine the livelihood strategies that they pursue, but also determine their ability to achieve or fail to achieve their livelihood outcomes. Increased food security and access to resources as a category under livelihood outcomes indicates that increase in food security and access to more resources are intimately interconnected. In this context, the level of access to resources of a household is likely to determine its food security. Arguably, increase in income and decrease in vulnerability as a category under livelihood outcomes indicates that the more income fisher folks have at their disposal, the less vulnerable and more resilient there are likely to be. Extra income generating activities associated with women also emerged in this category. In addition to fishing, wives of fishermen engage in other livelihood strategies. This implies that just like their male counterparts, women equally occupy an important position in terms of economic activities in rural coastal fishing communities (Mensah et al., 2006).

It is also interesting to note that it was documented in the findings that fisher folks within the communities under study belong to different categories in terms of achievements of their livelihood outcomes. This section classifies them in relation to their achievements, namely 'positive, 'mid' and negative' outcomes. The fisher folks who are able to achieve their identified livelihood outcomes are classified as positive outcome. Those classified as 'negative outcome', on the other hand, are tagged literally as 'poor' or 'poor people', while 'the hardworking people' fall under mid outcome. As foretold from the literature and the present study, most of the fisher folks within the positive outcome bracket have the opportunity to accumulate savings and invest in the human development of their children by either sending them to school or engaging them in learning some trade. Their livelihood strategies are well diverse and spread across at least one or two activities through which they earn additional income.

\section{CONCLUSIONS AND RECOMMENDATIONS}

There is a relationship between fisher folks' access to capital and the outcome of the livelihood strategies they pursue. Both the poor and well-off fisher folks pursue diversification and migration strategies. Individuals with more access to capital have the edge over those without or with less access in the pursuance of livelihood strategies. The poor fisher folks are forced to partake in low-income activities (strategies). In addition, the various livelihood outcomes that fisher folks aimed to achieve were to: 'reduced vulnerability', 'increase income', 'good health' and 'well-being', 'food security' as well as 'more access to assets'.

These elements were classified into three categories, namely, 'positive outcome', 'mid outcome' and 'negative outcome'. Most of the male fisher folks that pursue all the three identified livelihood strategies and the female fisher folks that follow only diversification achieved their livelihood outcomes, and by this belong to the 'positive' category. This group of fisher folks have enough access to capital as well as stable income generating activities. As such, they are able to ensure their well-being and that of members of their household through the provision of nutritious food and good health care, implying that they are least susceptible to vulnerability. Fisher folks belonging to this particular group are not only able to invest in the development of their children, but they are also very influential in their various communities in terms of decision-making. They included mostly boat, net owners and fish processors/traders.

Furthermore, fisher folks who strive to achieve their livelihood outcomes and thus, fall under the 'mid outcomes' are the young persons with small household sizes. Many of them follow migration and diversification strategies but earn medium income with less access to assets. They are, however, in the process of achieving their identified livelihood outcomes but are able to provide adequate health care and food for themselves and their household members.

Those in the 'negative' outcomes group are those who fail to achieve their livelihood outcomes. They constitute the highest population in all the four fishing communities. They are characterised by large household sizes, debts and less access to different types of capital, even though they engage in migration and diversification strategies. Although they work for long hours, they earn insufficient income to provide for proper daily meals, health care and clothing for themselves and their household members. As part of their strategies to survive, some resort to selling the labour of their children to generate income for the household instead of sending them to school. This highlights the endemic nature of poverty and vulnerability in the study communities.

The findings have policy implications. The government and other stake holders need to assess how different rural-poverty-reduction-based policies in Ghana's legislation and programmes can best support livelihood strategies of rural coastal fishing communities. In this context, greater consideration of the relationship between livelihood strategies and the provision of fishing inputs as well as credit facilities for rural fishing communities is necessary.

Also, poverty reduction policies aimed at promoting women in fishing communities should not focus only 
on those who are in the fishery business, but also on those who are involved in other income generating activities. Finally, frantic efforts should be made by all stakeholders in investing in livelihood activities within rural coastal fishing communities as a way of broadening fisher folks' entitlements and capabilities.

\section{REFERENCES}

Afenyedu, D. (2010). Child labour in fisheries and aquaculture: A Ghanaian perspective. A paper presented at the FAO workshop on child labour in fisheries and aquaculture at ILO FAO headquarters, Rome, Italy, April 14 - 16, 2010.

Allison, E. H., \& Ellis, F. (2001). The livelihood approach and management of small-scale fisheries. Marine Policy, 25(5), 377-388.

Akyeampong, E. (2007). Indigenous knowledge and maritime fishing in West Africa: The case of Ghana. Tribes and Tribals (Special Voume) 1, 173-182.

Anarfi, J. Kwankye. S., Ofosu-Mensah. A., \& Tiemoko, R. (2003). Migration from and to Ghana: A background paper. Sussex: Centre for Migration Research.

Baidoo, F. L., Dankwa, S., \& Eshun, I. (2018). Culture of vote buying and its implications: Range of incentives and conditions politicians offer to electorates. International Journal of Developing and Emerging Economies, 6(2), 1-20.

Béné, C., \& Heck, S. (2005). Fish and food security in Africa. NAGA Worldfish Center Quarterly, 28(3-4), 8-13.

Béné, C., Macfadyen, G., \& Allison, E. H. (2007). Increasing the contribution of small-scale fisheries to poverty alleviation and food security. Rome: FAO.

Bortei-Doku, A. E. (2002). Socio-economic aspects of artisanal marine fisheries management in West Africa. In J. McGlade (ed), The Gulf of Guinea large marine ecosystem. Amsterdam: Elsevier Science B.V.

De Haan, L. (2006). The livelihood approach and African livelihoods. Utretch: Utretch University.

De Haan, L., \& Zoomers, A. (2003). Development geography at the crossroads of livelihood and globalisation. TESG Journal of Economic and Social Geography, 94(3), 350-362.

DfID (2004). Post-harvest fisheries and poverty in Ghana. Retrieved from http:www.exerter.ac.uk/imm/Ghana\%20PH\%fhper\%202004a.pdf.

DfID (1999). Sustainable livelihoods guidance framework. Retrieved from: http://www.eldis.org/vfile/upload/1/document/0901/section2.pdf.

Dietz, T., Druijven, P., \& Foeken., D. (1992). Coping mechanisms and livelihood strategies-A summary of concepts. In H. Reitsma, T. Dietz \& L. De Haan, (eds), Coping with semi aridity: How the rural poor survive in dry-season environments (pp. 37-43). Amsterdam: University of Amsterdam.

Ellis, F. (2000). Rural livelihoods and diversity in developing countries. Oxford: Oxford University Press.

FAO/IFAD/WB (2009). Module 13: Gender in fisheries and aquaculture. In Gender in agriculture sourcebook (pp. 561-600). Washington D.C.: World Bank.

Farrington, J., Carney, D., Ashley, C., \& Turton, C. (1999). Sustainable livelihoods in practice: Early applications of concepts in rural areas. London: Overseas Development Institute (ODI).

Golo, H. K., Attom, L. E., Brew, E., \& Eshun, I. (2018). Human rights issues of child labour and economic activities: The way forward. American Journal of Social Science Research, 4 (2), 40-52.

Golo, H. K, \& Eshun, I (2018). Assessing climate change related events on the rights of subsistence in the rural coastal communities of Ghana. International Journal of Weather, Climate Change and Conservation Research, 4 (2), 1-17.

International Collective in Support of Fishworkers [ICSF] (2006). Understanding subsidies supporting fisheries: The WTO fisheries subsidies debate and developing-country priorities. Chennai: ICSF.

IMM (2003). Sustainable coastal livelihoods: Policy and coastal poverty in the Western Bay of Bengal. Exeter: The Innovative Drive, University of Exeter.

Kaag, M., van Berkel, J. R., Brons, M., De Bruijin H., \& van Dijk, J. W. M. (2003). Poverty is bad: Ways forward in livelihood research. Paper presented at the CERES Pathways of Development Seminar, Utrecht, $6^{\text {th }}$ February, 2003.

Kleih, U., Greenhalgh, P., \& Oudwater, N. (2003). A guide to the analysis of fish marketing systems using a combination of sub-sector analysis and the sustainable livelihood approach. Chatham: Natural Resources Institute.

Lenselink, N. M. (2002). Participation in artisanal fisheries management for improved livelihoods in West Africa - A synthesis of interviews and cases from Mauritania, Senegal, Guinea and Ghana. Rome: FAO.

Maxwell, D. (1999). Programmes in chronically vulnerable areas: Challenges and lessons learned. Disasters, 23(4), 373-384.

Mensah, M. A., Koranteng, K. A., Bortey, A., \& Yeboah, D. A. (2006). The state of world fisheries from a fishworker perspective: The Ghanaian situation. Chennai: ICSF.

Moser, C. (1998). The asset vulnerability framework: Reassessing urban poverty reduction strategies. World 
Development, 26(1), 1-19.

Platteau, J. (1989). The dynamics of fisheries development in developing countries: A general overview. Development and Change, 20(4), 565-597.

Rakodi, C. (2002). A livelihoods approach - Conceptual issues and definitions. In C. Rakodi, \& T. Lloyd-Jones (Eds), Urban livelihoods (pp. 3-22). London: Earthscan Publicatons Ltd.

Rakodi, C. (2001). Urban livelihoods: A people centred approach to reducing poverty. London: Earthscan Publications Ltd.

Scoones, I. (1998). Sustainable rural livelihoods: A framework for analysis. Sussex: Institute of Development Studies.

Tashakkori, A., \& Teddlie, C. (1998). Combining qualitative and quantitative approaches. Thousand Oak, California: Sage Publications Inc.

Townsley, P. (1998). Aquatic resources and sustainable rural livelihoods. In D. Carney (ed), Sustainable rural livelihoods: What contribution can we make? London: Department for International Development. 